\title{
Increased susceptibility to mammary carcinogenesis and an opposite trend in endometrium in Trp53 heterozygous knockout female mice by backcrossing the BALB/c strain onto the background $\mathrm{C} 3 \mathrm{H}$ strain
}

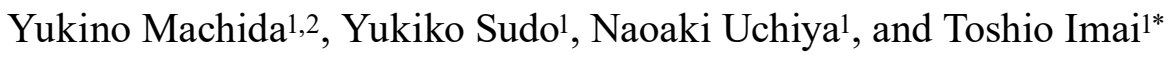 \\ ${ }_{1}^{1}$ Central Animal Division, National Cancer Center Research Institute, 5-1-1 Tsukiji, Chuo-ku, Tokyo 104-0045, Japan \\ ${ }_{2}^{2}$ Department of Veterinary Pathology, Nippon Veterinary and Life Science University, 1-7-1 Kyonancho, Musashino-shi, \\ Tokyo 180-8602, Japan
}

\begin{abstract}
Patients with dominantly inherited Li-Fraumeni syndrome have a loss-of-function mutation in TP53 and develop diverse mesenchymal and epithelial neoplasms at multiple sites. Trp $53^{+/-}$female mice with the BALB/c background provide unique characteristics for the study of breast cancer in Li-Fraumeni syndrome; however, we previously found that female C3H-Trp $53^{+/-}$mice did not spontaneously develop mammary tumors. Therefore, we obtained F1 and N2-N4 female mice by backcrossing the BALB/c strain and examined the incidence of mammary and other tumors in lifetime studies. Malignant lymphomas, osteosarcomas, and uterine adenocarcinomas spontaneously developed in approximately $20 \%$ or more of $\operatorname{Trp} 53^{+-}$mice with the C3H background. In contrast, the incidence of uterine adenocarcinomas showed a tendency to decrease, while that of mammary adenocarcinomas gradually increased in mice with the BALB/c strain backcross. Wild-type BALB/c female mice are predisposed to a wide spectrum of neoplasms, including mammary tumors, partly due to genetic factors, whereas uterine tumors are uncommon not only in BALB/c mice but also $\mathrm{C} 3 \mathrm{H}$ mice. Thus, genetic factors appear to contribute to a strain-specific predisposition to malignant neoplasms in $\operatorname{Trp} 53^{+/-}$mice, and further studies are needed to clarify the detailed mechanisms. (DOI: 10.1293/tox.2018-0057; J Toxicol Pathol 2019; 32: 197-203)
\end{abstract}

Key words: $\operatorname{Tr} p 53, \mathrm{BALB} / \mathrm{c}, \mathrm{C} 3 \mathrm{H}$, backcrossing, mammary carcinoma, uterine carcinoma

Patients with dominantly inherited Li-Fraumeni syndrome have a loss-of-function mutation in codon 245 (GGC to GAC) of TP53 and develop diverse mesenchymal and epithelial neoplasms at multiple sites, e.g., the breast, soft tissue, brain, bone, leukocytes, and adrenal cortex ${ }^{1,2}$. This mutation does not produce a mutant TP53 protein with a dominant negative effect, is expected to exert a trans-dominant loss-of-function effect on the wild-type TP53 protein, and is considered to increase susceptibilities to various tumors $^{2}$. In Trp53-deficient mouse models, homozygotes $\left(\operatorname{Trp} 53^{-/-}\right)$are highly susceptible to early onset spontaneous tumors. The most frequent tumor type was found to be malignant lymphoma in homozygotes, with an estimated background of $\sim 75 \%$ C57BL/6 (B6) and $\sim 25 \%$ 129/Sv strains ${ }^{3,4}$, followed by several testicular tumors, e.g., seminomas, Leydig cell tumors, and solid embryonal carcinomas of the testis, reflecting B6 and 129/Sv characteristics, respectively ${ }^{3}$.

Received: 17 October 2018, Accepted: 25 March 2019 Published online in J-STAGE: 25 April 2019

*Corresponding author: T Imai (e-mail: toimai@ncc.go.jp) C2019 The Japanese Society of Toxicologic Pathology This is an open-access article distributed under the terms of the Creative Commons Attribution Non-Commercial No Derivatives (c) $\$$ (by-nc-nd) License. (CC-BY-NC-ND 4.0: https:// (CC) ${ }_{\mathrm{BY}} \mathrm{NC}_{\mathrm{ND}}$ creativecommons.org/licenses/by-nc-nd/4.0/).
The incidence of neoplastic lesions in various organs, predominately including soft tissue sarcomas, is also high in Trp53-heterodeficient (Trp53+--) mice, but with a slower onset than in homozygotes ${ }^{4}$. Furthermore, Trp53 $3^{+-}$mice with the BALB/c background provide unique characteristics for the study of breast cancer 5 .

Previous studies using Trp53 $53^{+/}$mice with the BALB/c background demonstrated a greater susceptibility to mammary carcinomas than those with the B6 or 129/Sv background $^{5,}$. . In BALB/c-Trp53--- mice, the incidence of lymphomas and hemangiosarcomas was higher than that of mammary carcinomas7. Furthermore, the incidence of mammary carcinomas was lower in BALB/c-Trp $53^{-/-}$mice than in BALB/c-Trp53 $3^{+/-}$mice ${ }^{7}$. Less than $1 \%$ of wild-type and $\operatorname{Trp} 53^{+/-}$B6 mice developed mammary tumors 8,9 . Blackburn et al. reported that Trp53 $3^{+-}$F1 mice with a 50\% B6 and $50 \% \mathrm{BALB} / \mathrm{c}$ background developed mammary tumors at an incidence of $32 \%$, while $\mathrm{N} 2$ mice with a $75 \% \mathrm{BALB} / \mathrm{c}$ background developed mammary tumors at a significantly lower incidence $(45 \%)$ than BALB/c-Trp $53^{+/-}$mice $(65 \%)$ after long latency periods, suggesting that dominant and recessive $\mathrm{BALB} / \mathrm{c}$ alleles contribute to spontaneous mammary tumor susceptibility in $\operatorname{Tr} 553^{+-}$mice ${ }^{6}$. Blackburn et al. also indicated that a strong interaction between two $\mathrm{BALB} / \mathrm{c}$ alleles for the DNA-dependent protein kinase catalytic subunit $(P r k d c)$ and cyclin dependent kinase inhibitor 
2A $(C d k n 2 a)$ increased the incidence of mammary tumors, while the effects of these recessive alleles were restricted as major loci contributing to mammary tumor susceptibility ${ }^{6}$.

Mice with the $\mathrm{C} 3 \mathrm{H}$ strain background exhibit different spectra of spontaneous tumors from BALB/c, B6, or 129/ $\mathrm{Sv}$ strains. For example, male $\mathrm{C} 3 \mathrm{H} / \mathrm{HeN}$ mice exhibited high susceptibilities to spontaneous hepatocarcinogenesis ${ }^{10}$. Spontaneous mammary and ovary tumors were introduced in female $\mathrm{C} 3 \mathrm{H} / \mathrm{HeN}$ mice ${ }^{11-13}$, and the contribution of an exogenous mouse mammary tumor virus to mammary tumors was demonstrated ${ }^{14-16}$. To the best of our knowledge, limited information is currently available on the incidence of tumors in $\mathrm{C} 3 \mathrm{H}-\operatorname{Tr} p 53^{+/-}$mice. Therefore, the purpose of the present study was to characterize the susceptibilities of the $\mathrm{C} 3 \mathrm{H}$ and $\mathrm{BALB} / \mathrm{c}$ strains to carcinogenesis in $\operatorname{Tr} p 53^{+/-}$mice and investigate the incidence of spontaneous tumor development in $\mathrm{C} 3 \mathrm{H} \mathrm{F}$, as well as F1 and N2-N4 crossed with $\mathrm{BALB} / \mathrm{c}$ mice in lifetime studies.

Frozen sperm of C3H-Trp $53^{+-}$mice, in which the $\mathrm{Nco}$ I site in exon 2 of the $\operatorname{Trp} 53$ gene was heterozygously inserted by a neomycin phosphotransferase gene ${ }^{17}$, were obtained from Riken RBC (RBRC01361, Tsukuba, Ibaraki, Japan). In vitro fertilization (IVF) was performed with $\mathrm{C} 3 \mathrm{H} / \mathrm{HeN}$ and $\mathrm{BALB} / \mathrm{cA}$ mouse oocytes, and F0 and F1 pups, respectively, were delivered from ICR surrogate dams. N2-N4 mice were obtained by crossing with BALB/cA mice, which were purchased from CLEA Japan, Inc. (Tokyo, Japan). They were given free access to the standard chow diet CE2 (CLEA Japan) and filtered tap water and were housed up to 5 per plastic cage with woodchip bedding in an air-conditioned animal room maintained at $22^{\circ} \mathrm{C}$ (fluctuation range: within $1{ }^{\circ} \mathrm{C}$ ) and $55 \%$ relative humidity (fluctuation range: within $10 \%$ ) with a 12:12-h light-dark cycle. In the experiment, palpations of the cervix, thorax, and abdomen of awake mice were conducted weekly in order to detect subcutaneous, intrathoracic, or intraperitoneal nodules. When nodules accounted for more than $10 \%$ of the body weight of mice (the longest diameter of nodules was regularly greater than 10 $\mathrm{mm}$ ) or their conditions were poor, mice were euthanized under isoflurane anesthesia, and the inguinal mammary gland (fat pad), subcutaneous nodules, and organs/tissues with macroscopic abnormalities in the abdominal, thoracic, and cranial cavities were excised. All animal experiments were performed under protocols approved by the Committee for the Ethics of Animal Experimentation of the National Cancer Center. Seventy virgin female $\operatorname{Tr} p 53^{+/-}$mice of the following backgrounds were included: 16 recipient inbred $\mathrm{C} 3 \mathrm{H}(\mathrm{F} 0), 14$ of the initial outcross of $\mathrm{C} 3 \mathrm{H}$ and $\mathrm{BALB} / \mathrm{c}(\mathrm{F} 1)$, 15 of the first backcross BALB/c onto $\mathrm{C} 3 \mathrm{H}(\mathrm{N} 2), 12$ of the second backcross (N3), and 13 of the third backcross (N4).

Genotyping was performed as described previously ${ }^{17}$. The primers used were mixtures of (1) intron 1 upstream of exon 2, 5'-AATTGACAAGTTATGCATCCAACAGTACA-3'; (2) exon 4, 5'-ACTCCTCAACATCCTGGGGCAGCAACAGAT-3'; and (3) the neo sequence, 5'-GAACCTGCGTGCAATCCATCTT-3'.

Samples were fixed in $10 \%$ neutral buffered formalin, processed routinely, and embedded in paraffin wax. Sections (thickness of $3 \mu \mathrm{m}$ ) were stained with hematoxylin and eosin (HE) and histopathologically diagnosed. Paraffin-embedded sections were also used for immunohistochemistry for human ER $\alpha$ (Leica, Newcastle, UK; clone, 6F11; 1:100 dilution). Antigen retrieval for sections was conducted in an autoclave at $121^{\circ} \mathrm{C}$ for $10 \mathrm{~min}$ in $10 \mathrm{mM}$ citrate buffer $(\mathrm{pH}$ 6.0). The streptavidin-biotin-peroxidase complex method (StreptABComplex/HRP, DAKO, Glostrup Denmark) was used to assess the expression and localization of each antigen, and sections were lightly counterstained with hematoxylin for microscopic examinations. Negative controls without primary antibody reactions were set using serial sections. ER-positive mammary tumors were defined by the presence of more than $10 \%$ ER-positive tumor cells.

The Log-rank test was used to evaluate overall survival. Regarding the incidence of histopathologically diagnosed tumors, the $2 \times 5$ chi-squared test was performed among all 5 groups, and this was followed by Fisher's exact test between $\mathrm{F} 0$ and the remaining four groups when a significant difference was observed.

Survival rates were lower in N3 and N4 mice than in F0 mice ( $p=0.012$ and 0.028 , respectively; Fig. 1A-1E). Mammary tumors, which are described in detail below, sporadically developed in mice aged 38 to 82 weeks, and survival rates in $\mathrm{N} 3$ and $\mathrm{N} 4$ mice markedly decreased after approximately $40-50$ weeks of age. The shorter survival rates in N3 and N4 mice than in F0 mice were partly attributed to increased susceptibility to mammary carcinogenesis by backcrossing the $\mathrm{BALB} / \mathrm{c}$ strain onto the background $\mathrm{C} 3 \mathrm{H}$ strain.

No mammary tumors $(0 \%)$ were detected in $\mathrm{C} 3 \mathrm{H}-$ $\operatorname{Trp} 53^{+/-}$mice, whereas the incidence of mammary tumors in mice with the BALB/c strain backcross gradually increased ( $p=0.038$; Table 1, Fig. 2A). The incidence of mammary tumors was significantly higher in $\mathrm{N} 2, \mathrm{~N} 3$, and $\mathrm{N} 4$ mice than in $\mathrm{C} 3 \mathrm{H}(\mathrm{F} 0)$ mice $(p=0.043,0.008$, and 0.004 , respectively). All mammary tumors were adenocarcinomas, with most (11 out of 18,61\%) arising in the inguinal or gluteal areas, though 4 out of $18(22 \%)$ and 3 out of $18(17 \%)$ were detected in the thoracic or axillary areas and in submaxillary areas, respectively, in the remaining four groups. The cut surfaces of histopathologically diagnosed mammary adenocarcinomas macroscopically showed a lobular appearance and were opaque with a light yellow-white color. The histological types of all cases were ductal and lobular adenocarcinomas in F1, N2, and N3 mice. In adenocarcinomas with ductal/lobular differentiation, tumor cells mainly showed tubular, papillary, and/or solid patterns, sometimes grew with ribbon-like patterns, and were middle- to highgrade malignancies (Fig. 2B). In N4 mice, 4 out of the 6 $(67 \%)$ mammary tumors were ductal and lobular adenocarcinomas, while $2(33 \%)$ exhibited adenosquamous characteristics. ER $\alpha$-positive tumors were detected in 1 out of $3 \mathrm{~F} 1$ mice, 2 out of $4 \mathrm{~N} 2$ mice, 0 out of $4 \mathrm{~N} 3$ mice, and 2 out of 5 N4 mice (Fig. 2C).

The incidence of endometrial adenocarcinomas histopathologically showing the growth of malignant epithelia in 
A

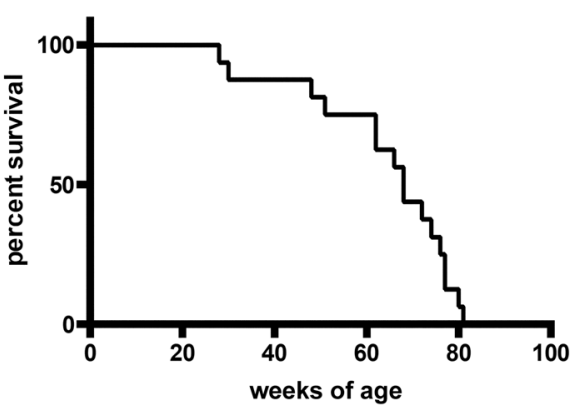

C

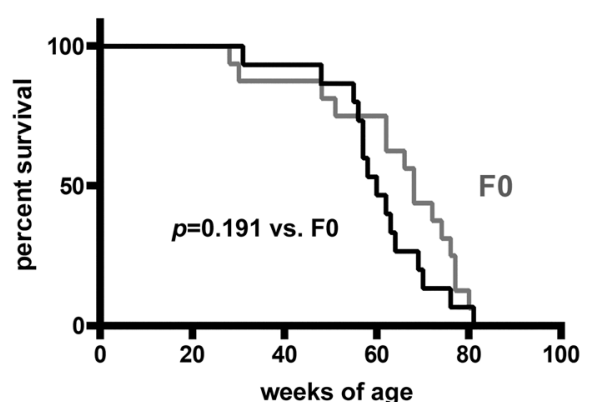

E

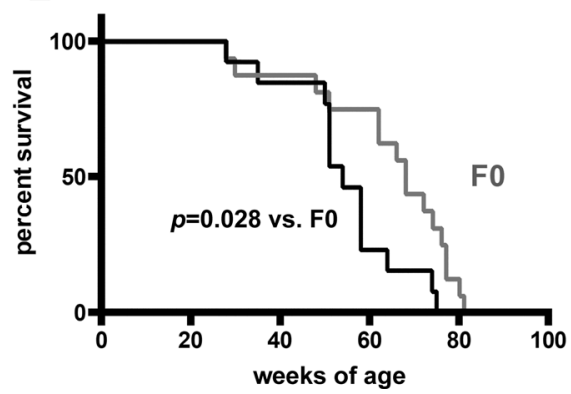

B

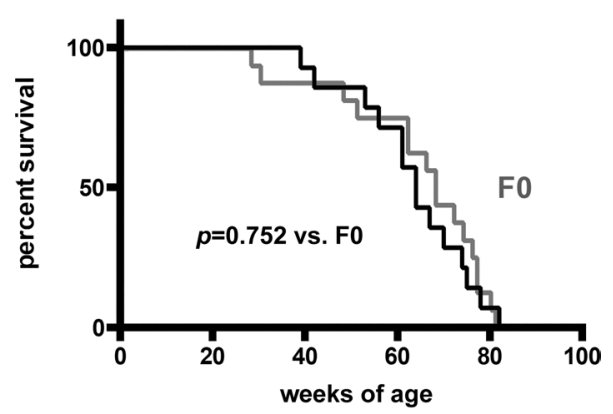

D

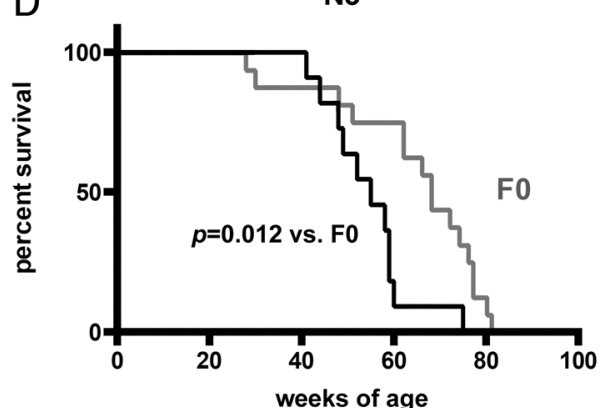

Fig. 1. Survival curves of (A) F0, (B) F1, (C) N2, (D) N3, and (E) N4 mice.

Table 1. Incidence of Mammary, Uterine, and Adrenal Tumors

\begin{tabular}{|c|c|c|c|c|c|c|c|c|c|c|c|c|c|}
\hline Organ & Finding & \multicolumn{2}{|c|}{ F0 } & \multicolumn{2}{|c|}{$\mathrm{F} 1$} & \multicolumn{2}{|c|}{ N2 } & \multicolumn{3}{|c|}{ N3 } & \multicolumn{2}{|c|}{ N4 } & Chi-squared test \\
\hline \multicolumn{14}{|c|}{ Mammary gland } \\
\hline & Adenocarcinoma & $0 / 16$ & $(0.0)$ & $3 / 14$ & $(21.4)$ & $4 / 15$ & $(26.7)$ & a & $5 / 12$ & $(41.7) \mathrm{b}$ & $6 / 13$ & $(46.2) \mathrm{b}$ & $p=0.038$ \\
\hline \multicolumn{14}{|c|}{ Uterus (endometrial epithelia) } \\
\hline & Adenocarcinoma & $3 / 16$ & $(18.8)$ & $1 / 14$ & (7.1) & $1 / 15$ & $(6.7)$ & & $0 / 12$ & $(0.0)$ & $0 / 13$ & $(0.0)$ & $p=0.269$ \\
\hline & Adenoma & $0 / 16$ & $(0.0)$ & $0 / 14$ & $(0.0)$ & $0 / 15$ & $(0.0)$ & & $0 / 12$ & $(0.0)$ & $1 / 13$ & $(7.7)$ & NT \\
\hline \multicolumn{14}{|c|}{ Adrenal } \\
\hline & Subcapsular cell carcinoma & $2 / 16$ & $(12.5)$ & $7 / 14$ & $(50.0)^{\mathrm{a}}$ & $6 / 15$ & $(40.0)$ & & $2 / 12$ & $(16.7)$ & $5 / 13$ & $(38.5)$ & $p=0.140$ \\
\hline & Subcapsular adenoma & $0 / 16$ & $(0.0)$ & $1 / 14$ & $(7.1)$ & $0 / 15$ & $(0.0)$ & & $1 / 12$ & $(8.3)$ & $0 / 13$ & $(0.0)$ & NT \\
\hline & Cortex adenocarcinoma & $0 / 16$ & $(0.0)$ & $1 / 14$ & (7.1) & $0 / 15$ & $(0.0)$ & & $0 / 12$ & $(0.0)$ & $0 / 13$ & $(0.0)$ & NT \\
\hline
\end{tabular}

${ }^{\mathrm{a}} p<0.05$ vs. F0 (Fisher's exact test); ${ }^{\mathrm{b}} p<0.01$ vs. F0 (Fisher's exact test); NT, not tested.

ductal and/or solid patterns (Fig. 2D) appeared to decrease with the crossing of $\mathrm{C} 3 \mathrm{H}-\mathrm{Tr} p 53^{+/-}$mice with $\mathrm{BALB} / \mathrm{c}$ mice; however, no significant differences were observed among the groups (Table 1). Other endometrial lesions were rare (Fig. 2A).

The incidence of adrenal subcapsular cell carcinomas is shown in Table 1. The total incidence of these carcinomas was higher in F1, N2, N3, and N4 mice (20/54, 37\%) than in $\mathrm{C} 3 \mathrm{H}(\mathrm{F} 0)$ mice, with no significant differences being observed among F0, F1, N2, N3, and N4 mice or marked increases with the crossing of $\mathrm{C} 3 \mathrm{H}-\operatorname{Trp} 53^{+/-}$mice with BALB/c mice. 
A
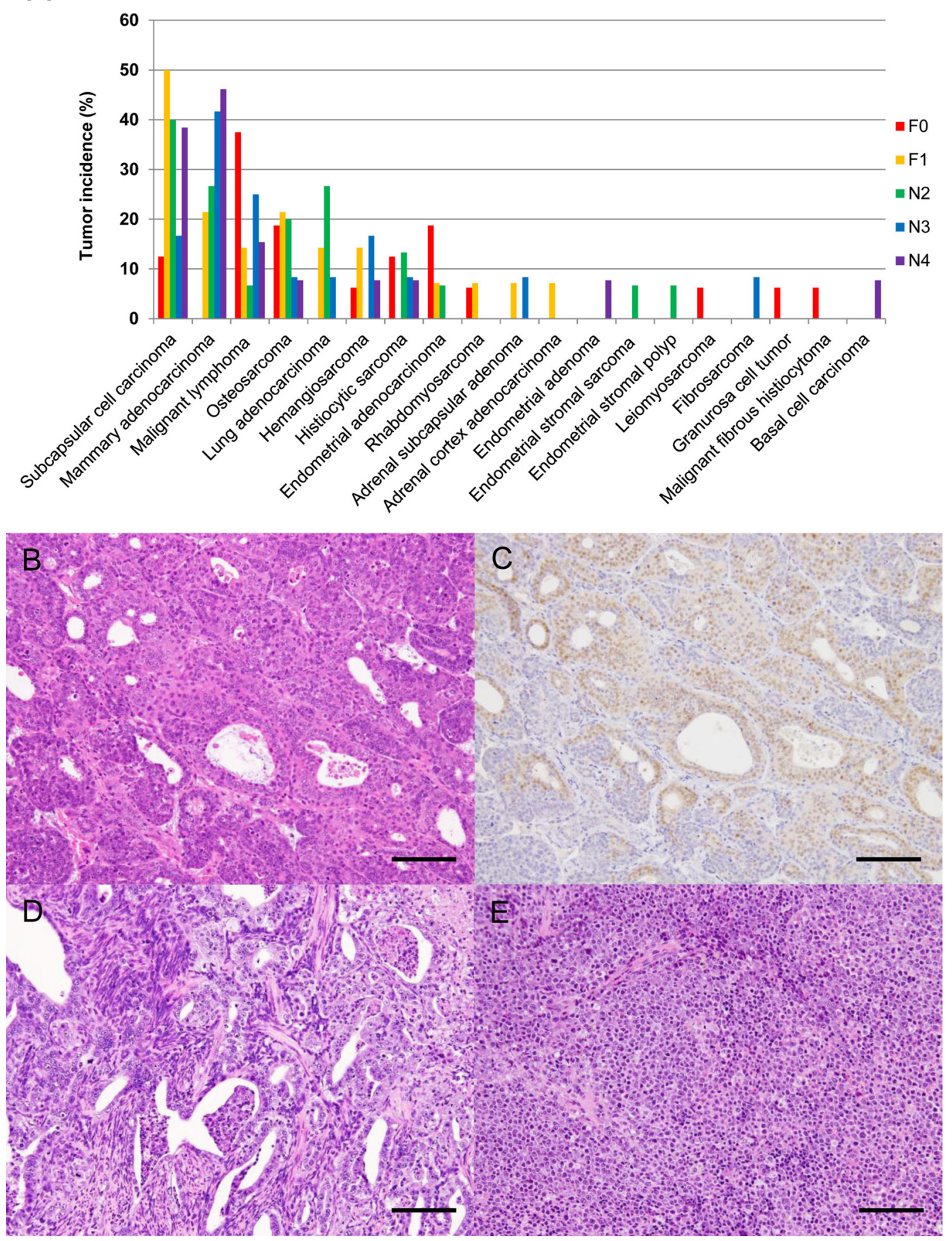

Fig. 2. (A) Overview of tumor histotype frequencies in F0, F1, N2, N3, and N4 mice. (B) In mammary tumors, tumor cells showed tubular, papillary, and/or solid patterns and were middle- to high-grade malignancies. An inguinal tumor of an N4 mouse. HE staining. (C) A serial section from the inguinal tumor in (B). ER $\alpha$ immunoreactivity is evident in epithelial cells. (D) In endometrial adenocarcinomas, malignant epithelial cells grew with ductal and solid patterns. A case of an F0 mouse. HE staining. (E) Lymphoid tumor cells frequently invaded the spleen, liver, and lungs. A splenic lesion in an F0 mouse. HE staining. Bar=100 $\mu \mathrm{m}(\mathrm{B}-\mathrm{E})$.

All cohorts also developed the other expected types of tumors, including lymphomas, osteosarcomas, and some mesenchymal and epithelial tumors (Fig. 2A), as reported previously in $\operatorname{Trp} 53^{+/-}$mice with other strain backgrounds ${ }^{4}$.
The most common spontaneous tumors observed in all cohorts were malignant lymphomas followed by osteosarcomas (Fig. 2A, 2E). Lung adenocarcinomas were observed in $\mathrm{F} 1, \mathrm{~N} 2$, and N3 mice, but not in F0 or N4 mice. As nonneo- 
plastic lesions, cystic hyperplasia of the uterus and ovaries was noted in the present study, which was consistent with previous findings obtained from BALB/c-Trp $53^{+/-}$mice ${ }^{18}$.

In the present study, F1, N2, N3, and N4 mice showed a gradually increasing incidence of mammary tumors, from $21 \%$ in $\mathrm{F} 1$ mice to $46 \%$ in N4 mice, and these results were consistent with previous findings $5,18,19$. The reason for this may be the unique functional polymorphism of Prkdc, which encodes a subunit of a DNA-dependent protein kinase involved in DNA double-strand break repair6, 19. We did not elucidate the mechanisms underlying mammary tumorigenesis in mice with the BALB/c background in the present study; however, BALB/c may have a germ line-specific factor that contributes to mammary tumor development, as discussed in the Introduction section. The $\mathrm{C} 3 \mathrm{H}$ parent strain was developed from a cross of a Bagg albino (which later produced BALB/c by inbreeding) female with a DBA male mouse, and they were genetically close ${ }^{20}$. Therefore, the use of these strains is advantageous for clarifying dominant genetic factors in mammary tumorigenesis and may lead to the development of better breast cancer mouse models.

Mouse models of estrogen receptor-positive (ER+) breast cancer have been reviewed ${ }^{21}$. Esrl, Ccndl, Prl, Tgfa, Ncoa3, Espl1, and Wnt1 overexpression, Pik3ca gain-offunction, and the loss of Statl were shown to be associated with mouse ER+ mammary carcinogenesis ${ }^{21}$. Based on the phenotypes of the mammary tumors that developed, FVB-Tg(C3-1-TAg)cJeg (C3-TAg) mice have genetic drivers for tumorigenesis, which is very relevant to the human basal-like disease 22,23 . On the other hand, FVB/N$\mathrm{Tg}$ (MMTVneu)202Mul/J (MMTV-Neu) mice develop mammary tumors that represent a human luminal subtype but do not express ER ${ }^{23-26}$. Under these conditions, BALB/ c-Trp53 $3^{+/-}$mice are regarded as a typical ER+ mammary carcinoma model with acinar-type adenocarcinoma or adenoacanthoma phenotypes and occasional poorly differentiated carcinomas 5 . The Trp53-related model developed in BALB/c mice uses implants of the mammary epithelium from eight-week-old female mice with the germ-line loss of Trp53 that are placed into the cleared mammary fat pads of three-week-old mice in order to generate a mouse model of human ductal carcinoma in situ ${ }^{27}$. Implanted mice develop disease at an incidence of between 24 and 55\% 11 or 12 months after implantation, and $21 \%$ of lesions are ER+27. These findings are consistent with the present results showing that the incidence of spontaneously induced ER+ mammary tumors was approximately $30 \%$.

There are currently only a few animal models of uterine carcinogenesis, e.g., Donryu rats treated with or without $N$-ethyl- $N$ '-nitro- $N$-nitrosoguanidine ${ }^{28}$. In Donryu rats, poorly differentiated adenocarcinomas were found to be positive for the Trp53 protein, suggesting the accumulation of mutated $\operatorname{Trp} 53^{28}$. Furthermore, Mitsumori et al. generated a uterine carcinogenesis model that was useful for identifying the tumor-modifying effects of endocrine-disrupting chemicals following the administration of $N$-ethyl- $N$-nitrosourea to female CBA-Trp53 ${ }^{+/-}$mice ${ }^{29}, 30$. In the present study, uterine adenocarcinomas were spontaneously detected in approximately $19 \%(3 / 16)$ of $\operatorname{Trp} 53^{+-}$mice with the $\mathrm{C} 3 \mathrm{H}$ background. Donehower et al. reported that the loss of Trp53 function was sufficient to genetically predispose mice to the spontaneous development of tumors, e.g., malignant lymphomas and testicular tumors in $\operatorname{Trp} 53^{+/}$mice with the C57BL6 and 129/Sv backgrounds, respectively ${ }^{3}$. Szymanska et al. recently showed that wild-type BALB/c female mice developed a wide spectrum of neoplasms, including mammary tumors, which is consistent with the present results as well as previous findings. On the other hand, wild-type DBA mice frequently $(\sim 25 \%)$ developed uterine tumors, which are uncommon not only in BALB/c mice but also in $\mathrm{C} 3 \mathrm{H}$ wild-type mice ${ }^{31}$. The $\mathrm{C} 3 \mathrm{H}$ parent strain was developed from a cross of a Bagg albino female with a DBA male mice, and $\mathrm{C} 3 \mathrm{H}$ and DBA strains are genetically close $^{20}$. In addition, Wall et al. reported clear strain differences in uterine physiological factors between C57BL6 and $\mathrm{C} 3 \mathrm{H}$ female mice, e.g., cell proliferation/apoptosis indicators and gene transcripts under conditions with and without estrogen ${ }^{32}$. Therefore, the uterine tumors observed in Trp $53^{+/-}$mice with the $\mathrm{C} 3 \mathrm{H}$ background in the present study are considered to be of biological significance and may have been influenced by $\mathrm{C} 3 \mathrm{H}$-specific genetic factors in addition to uterine environment factors.

In conclusion, backcrossing the BALB/c strain onto the background $\mathrm{C} 3 \mathrm{H}$ strain resulted in a slight decrease in the incidence of uterine adenocarcinomas but also a gradual increase in mammary adenocarcinomas in $\operatorname{Tr} p 53^{+/-}$mice. The present results suggest that genetic factors partly contribute to a strain-specific predisposition to malignant neoplasms in $\operatorname{Tr} 53^{+/-}$mice, and further studies are needed to clarify the detailed mechanisms.

Disclosure of Potential Conflict of Interest: The authors declared no potential conflicts of interest with respect to the research, authorship, and/or publication of this article.

Acknowledgments: We thank the Animal Core Facility of the National Cancer Center Research Institute for maintaining mice and for their technical support with histopathological evaluations. The Core Facility was supported by the National Cancer Center Research and Development Fund (29-A-2). This work was supported in part by the National Cancer Center Research and Development Fund (26-A-8) and a Health and Labor Sciences Research Grant from the Ministry of Health, Labor and Welfare of Japan.

\section{References}

1. Srivastava S, Zou ZQ, Pirollo K, Blattner W, and Chang EH. Germ-line transmission of a mutated $\mathrm{p} 53$ gene in a cancer-prone family with Li-Fraumeni syndrome. Nature. 348: 747-749. 1990. [Medline] [CrossRef]

2. Malkin D, Li FP, Strong LC, Fraumeni JF Jr, Nelson CE, Kim DH, Kassel J, Gryka MA, Bischoff FZ, Tainsky MA, et al. Germ line p53 mutations in a familial syndrome of 
breast cancer, sarcomas, and other neoplasms. Science. 250: 1233-1238. 1990. [Medline] [CrossRef]

3. Donehower LA, Harvey M, Slagle BL, McArthur MJ, Montgomery CA Jr, Butel JS, and Bradley A. Mice deficient for p53 are developmentally normal but susceptible to spontaneous tumours. Nature. 356: 215-221. 1992. [Medline] [CrossRef]

4. Harvey M, McArthur MJ, Montgomery CA Jr, Butel JS, Bradley A, and Donehower LA. Spontaneous and carcinogen-induced tumorigenesis in p53-deficient mice. Nat Genet. 5: 225-229. 1993. [Medline] [CrossRef]

5. Kuperwasser C, Hurlbut GD, Kittrell FS, Dickinson ES, Laucirica R, Medina D, Naber SP, and Jerry DJ. Development of spontaneous mammary tumors in BALB/c p53 heterozygous mice. A model for Li-Fraumeni syndrome. Am J Pathol. 157: 2151-2159. 2000. [Medline] [CrossRef]

6. Blackburn AC, Brown JS, Naber SP, Otis CN, Wood JT, and Jerry DJ. BALB/c alleles for Prkdc and Cdkn2a interact to modify tumor susceptibility in Trp53+/- mice. Cancer Res. 63: 2364-2368. 2003. [Medline]

7. Landuzzi L, Ianzano ML, Nicoletti G, Palladini A, Grosso V, Ranieri D, Dall'Ora M, Raschi E, Laranga R, Gambarotti M, Picci P, De Giovanni C, Nanni P, and Lollini PL. Genetic prevention of lymphoma in p53 knockout mice allows the early development of p53-related sarcomas. Oncotarget. 5: 11924-11938. 2014. [Medline] [CrossRef]

8. Heston WE, and Vlahakis G. Mammary tumors, plaques, and hyperplastic alveolar nodules in various combinations of mouse inbred strains and the different lines of the mammary tumor virus. Int J Cancer. 7: 141-148. 1971. [Medline] [CrossRef]

9. Jacks T, Remington L, Williams BO, Schmitt EM, Halachmi S, Bronson RT, and Weinberg RA. Tumor spectrum analysis in p53-mutant mice. Curr Biol. 4: 1-7. 1994. [Medline] [CrossRef]

10. Falvella FS, Pascale RM, Gariboldi M, Manenti G, De Miglio MR, Simile MM, Dragani TA, and Feo F. StearoylCoA desaturase 1 (Scd1) gene overexpression is associated with genetic predisposition to hepatocarcinogenesis in mice and rats. Carcinogenesis. 23: 1933-1936. 2002. [Medline] [CrossRef]

11. Takahashi Y, Nakatsuru Y, Zhang S, Shimizu Y, Kume H, Tanaka K, Ide F, and Ishikawa T. Enhanced spontaneous and aflatoxin-induced liver tumorigenesis in xeroderma pigmentosum group A gene-deficient mice. Carcinogenesis. 23: 627-633. 2002. [Medline] [CrossRef]

12. Kossoy G, Anisimov VN, Ben-Hur H, Kossoy N, and Zusman I. Effect of the synthetic pineal peptide epitalon on spontaneous carcinogenesis in female $\mathrm{C} 3 \mathrm{H} / \mathrm{He}$ mice. In Vivo. 20: 253-257. 2006. [Medline]

13. Frith $\mathrm{CH}$, Zuna RE, and Morgan K. A morphologic classification and incidence of spontaneous ovarian neoplasms in three strains of mice. J Natl Cancer Inst. 67: 693-702. 1981. [Medline]

14. Vaage J, Smith GH, Asch BB, and Teramoto Y. Mammary tumorigenesis and tumor morphology in four $\mathrm{C} 3 \mathrm{H}$ sublines with or without exogenous mammary tumor virus. Cancer Res. 46: 2096-2100. 1986. [Medline]

15. Maillard I, Luthi F, Acha-Orbea H, and Diggelmann H. Role of the immune response induced by superantigens in the pathogenesis of microbial infections. Parasitology. 115(Suppl): S67-S78. 1997. [Medline] [CrossRef]
16. Jackson L. C3H strain free of exogenous MMTV. JAX Notes. 480: 8. 2000.

17. Tsukada T, Tomooka Y, Takai S, Ueda Y, Nishikawa S, Yagi T, Tokunaga T, Takeda N, Suda Y, Abe S, et al. Enhanced proliferative potential in culture of cells from p53-deficient mice. Oncogene. 8: 3313-3322. 1993. [Medline]

18. Koch JG, Gu X, Han Y, El-Naggar AK, Olson MV, Medina D, Jerry DJ, Blackburn AC, Peltz G, Amos CI, and Lozano G. Mammary tumor modifiers in BALB/cJ mice heterozygous for p53. Mamm Genome. 18: 300-309. 2007. [Medline] [CrossRef]

19. Yu Y, Okayasu R, Weil MM, Silver A, McCarthy M, Zabriskie R, Long S, Cox R, and Ullrich RL. Elevated breast cancer risk in irradiated $\mathrm{BALB} / \mathrm{c}$ mice associates with unique functional polymorphism of the Prkdc (DNA-dependent protein kinase catalytic subunit) gene. Cancer Res. 61: 1820-1824. 2001. [Medline]

20. Schalkwyk LC, Jung M, Daser A, Weiher M, Walter J, Himmelbauer $\mathrm{H}$, and Lehrach $\mathrm{H}$. Panel of microsatellite markers for whole-genome scans and radiation hybrid mapping and a mouse family tree. Genome Res. 9: 878-887. 1999. [Medline] [CrossRef]

21. Dabydeen SA, and Furth PA. Genetically engineered ER $\alpha$ positive breast cancer mouse models. Endocr Relat Cancer. 21: R195-R208. 2014. [Medline] [CrossRef]

22. Maroulakou IG, Anver M, Garrett L, and Green JE. Prostate and mammary adenocarcinoma in transgenic mice carrying a rat C3(1) simian virus 40 large tumor antigen fusion gene. Proc Natl Acad Sci USA. 91: 11236-11240. 1994. [Medline] [CrossRef]

23. Herschkowitz JI, Simin K, Weigman VJ, Mikaelian I, Usary J, Hu Z, Rasmussen KE, Jones LP, Assefnia S, Chandrasekharan S, Backlund MG, Yin Y, Khramtsov AI, Bastein R, Quackenbush J, Glazer RI, Brown PH, Green JE, Kopelovich L, Furth PA, Palazzo JP, Olopade OI, Bernard PS, Churchill GA, Van Dyke T, and Perou CM. Identification of conserved gene expression features between murine mammary carcinoma models and human breast tumors. Genome Biol. 8: R76. 2007. [Medline] [CrossRef]

24. Muller WJ, Arteaga CL, Muthuswamy SK, Siegel PM, Webster MA, Cardiff RD, Meise KS, Li F, Halter SA, and Coffey RJ. Synergistic interaction of the Neu proto-oncogene product and transforming growth factor alpha in the mammary epithelium of transgenic mice. Mol Cell Biol. 16: 5726-5736. 1996. [Medline] [CrossRef]

25. Gruvberger S, Ringnér M, Chen Y, Panavally S, Saal LH, Borg A, Fernö M, Peterson C, and Meltzer PS. Estrogen receptor status in breast cancer is associated with remarkably distinct gene expression patterns. Cancer Res. 61: 5979-5984. 2001. [Medline]

26. Pfefferle AD, Herschkowitz JI, Usary J, Harrell JC, Spike BT, Adams JR, Torres-Arzayus MI, Brown M, Egan SE, Wahl GM, Rosen JM, and Perou CM. Transcriptomic classification of genetically engineered mouse models of breast cancer identifies human subtype counterparts. Genome Biol. 14: R125. 2013. [Medline] [CrossRef]

27. Medina D, Kittrell FS, Shepard A, Stephens LC, Jiang C, Lu J, Allred DC, McCarthy M, and Ullrich RL. Biological and genetic properties of the p53 null preneoplastic mammary epithelium. FASEB J. 16: 881-883. 2002. [Medline] [CrossRef]

28. Yoshida M, Katsuda S, and Maekawa A. Involvements of 
estrogen receptor, proliferating cell nuclear antigen and p53 in endometrial adenocarcinoma development in Donryu rats. J Toxicol Pathol. 25: 241-247. 2012. [Medline] [CrossRef]

29. Mitsumori K, Onodera H, Shimo T, Yasuhara K, Takagi H, Koujitani T, Hirose M, Maruyama C, and Wakana S. Rapid induction of uterine tumors with p53 point mutations in heterozygous p53-deficient CBA mice given a single intraperitoneal administration of N-ethyl-N-nitrosourea. Carcinogenesis. 21: 1039-1042. 2000. [Medline] [CrossRef]

30. Mitsumori K, Shimo T, Onodera H, Takagi H, Yasuhara K, Tamura T, Aoki Y, Nagata O, and Hirose M. Modifying effects of ethinylestradiol but not methoxychlor on N-ethyl$\mathrm{N}$-nitrosourea-induced uterine carcinogenesis in heterozy- gous p53-deficient CBA mice. Toxicol Sci. 58: 43-49. 2000. [Medline] [CrossRef]

31. Szymanska H, Lechowska-Piskorowska J, Krysiak E, Strzalkowska A, Unrug-Bielawska K, Grygalewicz B, Skurzak HM, Pienkowska-Grela B, and Gajewska M. Neoplastic and nonneoplastic lesions in aging mice of unique and common inbred strains contribution to modeling of human neoplastic diseases. Vet Pathol. 51: 663-679. 2014. [Medline] [CrossRef]

32. Wall EH, Hewitt SC, Liu L, del Rio R, Case LK, Lin CY, Korach KS, and Teuscher C. Genetic control of estrogenregulated transcriptional and cellular responses in mouse uterus. FASEB J. 27: 1874-1886. 2013. [Medline] [CrossRef] 